\title{
The Impact of the Internet on the Readership of Periodical Press
}

\author{
Faculty of Mass Media Communication Univerzity of Ss. Cyril and Methodius in Trnava, Nám. J. Herdu 2, 91701 Trnava, \\ Slovak Republic
}

\begin{abstract}
This paper deals with the impact of the internet on the readership figures of periodicals. Its aim is to examine the popularity of traditional editions of newspapers and magazines and compare the opinions of three generations of respondents on the questions regarding the use of their online versions in the shape of the number of visits to news websites. Furthermore, it looks at the respondents' views of the imposition of charges upon content published on the internet and the overall willingness to pay for such information.
\end{abstract} figures

Index Terms - internet, print media, circulation, readership

\section{Introduction}

Out of the many problems the market with periodicals has to cope with, the predominant part are economic issues. According to Višnovský [1] the basic problems of periodicals in Slovakia and abroad include the readership drop, the decreasing circulation of newspapers and magazines, diminishing advertising revenues, the sharpening battle for readers, the impact of new media, the increasing supply of information in the form of informational news and the press readers' changing information needs.

The role of information technologies, computer networks and communication is more important than it has ever been. They facilitate the transmission and sharing of data. It enables us to communicate, share information, learn and socialise online [2].

The innovation of the technological environment and the dramatic development of new means of communication have brought new opportunities for the use of journalism on the internet, which has hitherto existed solely in the traditional media such as the print media, television and radio broadcasting. To be able to maintain competitiveness and keep up with the best of the best, publishing houses have to devote appropriate attention to innovation. It means constantly coming up with new ideas which are predominantly connected with the use of new communication technologies.

As a result of the publishing houses' rising costs, the prices of newspapers and magazines are increasing, whereas, at the same time, the purchasing power of the population is decreasing. Accordingly, this leads to a significant drop in readership figures of print media with daily newspapers being most affected. As far as daily newspapers are concerned, however, they are reliant on the advertising revenues more than ever. The downward trend in the sales of periodicals has been noticeable continuously since 2010. At the beginning of last year, the average daily sales of five national newspapers saw a $9.3 \%$ decrease, compared with the same period of the previous year. While in January 2012 five monitored national dailies sold 294,000 copies, in January 2013 it was 269,000 and in January 2014 only 244,000 copies. The most significant drop was recorded in the January 2014 sales of the specialized economic daily Hospodárske noviny.

Due to the rapid decrease in circulation, publishing houses are forced to innovate the way of making information available by means of new information technologies. Slovak periodicals follow suit and are not lagging behind in innovations. By following the latest trends and producing electronic versions of their titles they strive to be accessible to their readers in the fastest and simplest way.

\section{Traditional vs. New Media}

Generally, the media can be divided into print media and electronic media. With respect to their historical development and characteristics they show, however, they can be divided into several different categories, usually into traditional and new media.

Depending on the circumstances, the differences among particular types of media might be blurred or mingled, e.g. picture or video might be displayed on a TV screen as well as a computer monitor or a mobile phone screen. Each of them represents a different type with distinctive and specific characteristics. Secondly, besides their paper (print) version, newspapers and magazines are also available in electronic format, which also represent two distinct types of media.

The category of traditional media includes newspapers, magazines, radio broadcasting and television. With respect to the historical development, they are the oldest, hence the attribute traditional. Because of their ability to address a wide range of audiences they are often labelled as mass media. As stated by Pizano and Kusá, they are carriers of 'traditional' forms marketing communication which form a strong mutual relationship between the subjects by means of proven and usual procedures. [3]

The television occupies a dominant position among the traditional media. Since, compared with other media, we devote most of our free time to watching television, this type of media can be considered the most used among the traditional types. According to Hradiská [4], television's appeal lies in the fact that the TV screen is a place where a whole range of events and relationships play out. A televised event gives the impression of one which is convincing; it bears the confirmation that it really happened, it is significant and there is a reason to be interested in it. As stated by McLuhan [5] 'TV engages its audience in action, where the programme 
attaining the best effect is the one in which the viewer has to complete certain processes.' Compared with radio broadcasting and periodicals it is best placed to draw the attention of the recipient. The viewer perceives the televised content through several senses, thereby having wider space for the perception. However, Hradiská [4] pointed out several other barriers to perception, mainly the passivity in attention, selectiveness of perception and the impact of experience.

The second most frequently used type of media in this group is newspapers and magazines. Historically, these are the oldest types of media. However, in the course of time and thanks to technological advancement, they were overtaken by television, and similarly, at present they are being replaced by the internet. While both of these groups of periodicals (newspapers and magazines) have common basic characteristics (topicality, periodicity and publicity), they differ mainly in their content and publication frequency as well as the structure of their advertising space and the journalist and non-journalistic content ratio. Newspapers are a type of periodicals with general-interest content, published at certain intervals at least once a week. Tušer [6] defined the newspaper as 'a periodical publication, which has a mass character and is published in regular one-day, two-day or longer intervals, and has a general-interest content processed in the form of opinion journalism, news reporting as well as non-journalistic content.' On the contrary, magazines are a type of periodicals with specialized content. Compared to newspapers, they have a lower publication frequency and a different way of processing information, with a predominant proportion of opinion journalism and non-journalistic content. They are defined as 'periodical publications with specialized content, having a lower publication frequency of at least two issues per year [6].

According to Hradiská [4] the relationship between the reader and the newspaper is determined from multiple aspects. The perception of newspapers requires increased mental activity and it is affected by several factors. Apart from the position of the title within the media system and the overall image of the periodical, there are other things which influence the reader, including the final form of processing and presentation of information, the font properties like font type, size and weight as well as the overall graphic design of the issue. Consequently, the current trend in the graphic design of periodicals is gradually shifting towards perfecting the graphic layout of individual issues.

Radio broadcasting represents the third and final type among the so called traditional media. Its characteristic feature is the recipients' background listening, thanks to which the listener is accompanied by radio throughout the day. Simultaneously, radio broadcasting's other attribute is evanescence, meaning the listener has limited ability to actually remember a lot of the information heard. As pointed out by Hradiská [4], the process of understanding the information broadcast by radio is connected with the limitation of the recipient's reception to speech, music and other sounds.

With regards to their massive development and use, the new media form a separate category of media. They are characterised by their interactive communication capability via the internet and include classic internet websites, social networks and various mobile applications which provide the latest information. News websites, which were established alongside the traditional media (newspapers and magazines), can also be regarded as part of new media as they gradually formed a separate category. On one hand, the perception of these types of media has numerous shared characteristics with the perception of traditional media, on the other hand they are also characterised by several particularities. New media enable interactive interconnection of audio, audiovisual as well as separate visual information into a coherent whole, which has not so far been offered to the recipient by any other type of media. Moreover, the online environment boasts the advantage of commanding unlimited space and easy accessibility at any time chosen by the recipient. As emphasized by Solík [7] communicating through electronic media blurs the traditional notions of time and space and the links between them.

Finally, there is a distinctive category of the so called specialized media, comprising media from previous classification, which are distinguished by specialized content such as professional journals, television channels and radio stations and specialized news websites.

\section{The Impact of the Internet on Newspaper and Magazine Readership}

In the recent years, the internet has had a significant impact on all traditional media including periodicals. Media are constantly trying to adapt to changing conditions on the market, react to current trends and adapt to changes in consumer behaviour [8]. Owing to relentless pressure of innovations, they are incessantly developing new formats and create a more attractive content. This trend is most significant in the field of periodicals, which, as a result of the development of internet and digital technologies, created a new type of media combining the advantages of traditional media and offering new possibilities of their use.

As a result of the changes mentioned above, a lot of editorial boards have begun publishing their articles online. Gradually, this gave rise to a lot of news websites and separate online editorial offices, which essentially replaced the original printed editions of newspapers and magazines. Having the option to obtain the same information online for free, many readers now found the purchase of traditional printed newspapers useless. In this way, the internet not only influenced the means of getting and processing information, but also substantially altered the consumer behaviour of current readers, namely the young generation. Under the influence of various technological innovations, this generation use the most modern ways of getting information and overview of the current affairs. However, several questions arise in the context of the future of traditional media as well as questions related to paying for the information published online.

According to the results of a telephone survey carried out in the UK in summer 2011 [9], reading daily periodical press is the third most common way of using tablets after regular surfing and emailing. Therefore, there are grounds for expecting that it will be tablets which will replace traditional 
print media like newspapers and magazines. On the other hand, the question remains whether tablet users will be willing to pay for the online content. To illustrate, as many as $53 \%$ of respondents of the above-mentioned survey stated that they read news using their tablets daily. $77 \%$ of the respondents stated that they read news at least once a week and it was thanks to the tablet that they read daily news more frequently than they had before. Nevertheless, only $14 \%$ of them said they were willing to pay for this information. $23 \%$ of the respondents said they had a digital subscription to content on some portals.

The indicated trend along with the facts stated above incited us to our own empirical research, whose aim was to compare the opinions of three generations of readers of periodical press in the 20-35, 35-50 and over -50 age groups. We attempted to find out the answers to the following questions: do the target group of respondents read the print media; what is the popularity of electronic editions of newspapers and newspapers among the particular target group; what are the opinions of the target group on imposing charge on online content; is the target group willing to pay for online content. The data collection was carried out in the form of electronic questionnaires between 11th - 15th December 2014 using the CAWI method (Computer Aided Web Interviewing) and it was based on the sample of 513 respondents. The structure of respondents is shown in Graph 1.

As emerged from the survey results, the age played an important role in nearly all of the observed areas. The differences were manifested not only in the questions about readership of traditional editions of newspapers and magazines, but also in the news websites visits. While the oldest generation of respondents (above 50 years old) read periodicals in its so called paper form $(29.5 \%$ read the periodical press 'several times per week', $43.6 \%$ read it 'once a week' and nearly $17 \%$ read it 'once a month'), the youngest generation of respondents visited the news websites $(88 \%$ of them daily, the remaining part once a week and once a month).

On the contrary, the older and the middle generations' visits to news websites were less frequent $(80 \%$ of respondents at the age of $35-50$ and $29 \%$ of respondents over the age of 50). $26 \%$ of the respondents at the age of $35-50$ and $32 \%$ of the respondents over 50 did not visit news websites at all. The youngest generation read the traditional printed editions of newspapers and magazines with the frequency of 'several times per month' (43\%), followed by 'once a week' $(24 \%)$ and 'once a month' $(21.6 \%)$. The results are shown in Graph 2 and Graph 3.

In addition to previous findings, we also observed differences in the willingness to pay for the information published on the internet. In this regard, the 35-50 age group turned out to be the most willing to pay for such content $(46 \%$ of those who visit news websites). The respondents from the youngest generation used the service of paid online content almost in $28 \%$ of cases. The least willingness to pay for online information was most notable in the oldest generation, with only $14.5 \%$ of those visiting news websites used the service of paid online content.
In contrast, almost $65 \%$ of the respondents at the age of 25-35 rejected to pay for content which is published on the internet. What is more, according to $91 \%$ of those respondents from this age group who visit news websites, the reason for these visits is getting information for free. Looking at the other generations, $35 \%$ of respondents at the age of 35-50 and almost $34 \%$ of respondents over the age of 50 said they refused to pay for content published online. In addition, $88 \%$ of the respondents from the middle generation and $37.5 \%$ of the respondents from the older generation claimed that they visited news websites because of the free information. Interestingly, news websites are the main source of information for as many as $78 \%$ of the respondents from the 20-35 age group, $36 \%$ of respondents from the 35-50 age group and only $6 \%$ of respondents from the over 50 age group. The results are shown in Graph 4.

Conversely, 91.5 of respondents from the over 50 age group considered reading newspapers or magazines in their traditional (paper) form more convenient than visiting news websites. What is surprising, however, is that as many as $43 \%$ of respondents from the 20-35 age group were of the same opinion, despite the fact that they visit news websites much more often.

To conclude, the readership of periodical press in relation to the impact of the internet is strongly related to the age of the reader. It has proved to be decisive in nearly all of the researched areas. The most significant impact of the internet was manifested in the issues of readership of newspapers and magazines, the popularity of news websites but also in the willingness to pay for the information published on the internet.

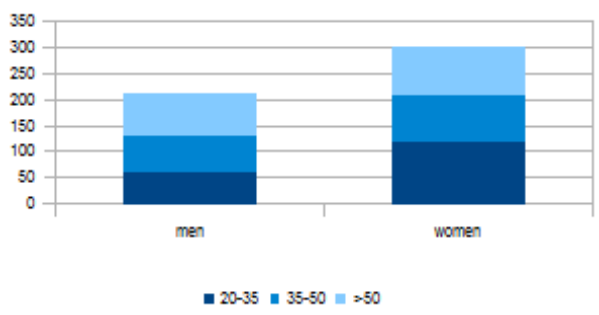

Graph 1 Structure of respondents.

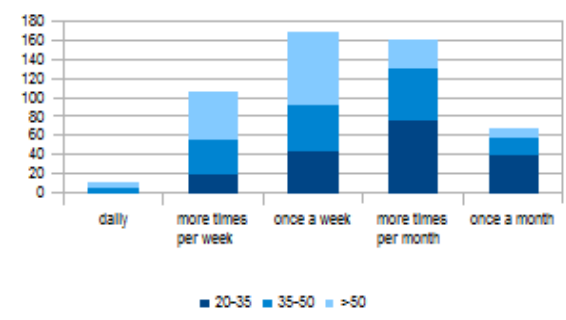

Graph 2 Readership of traditional editions of newspapers and magazines. 


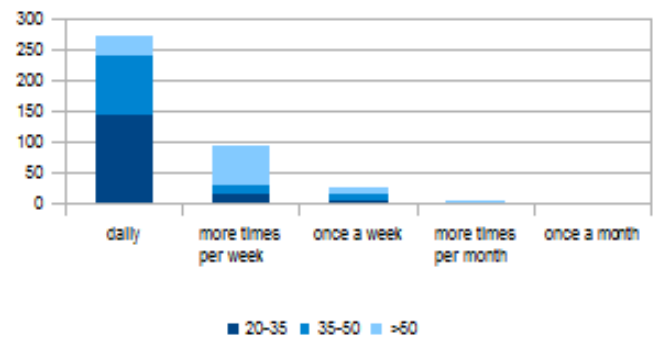

Graph 3 News websites visits.

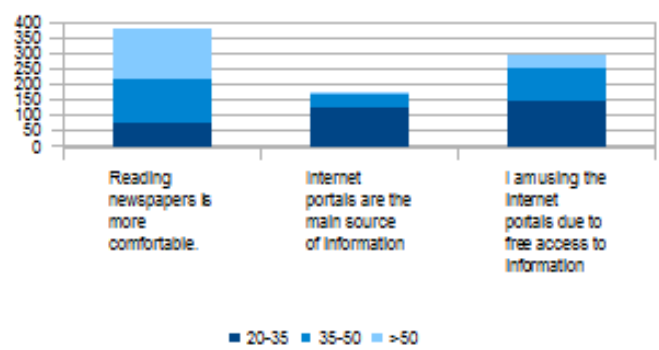

Graph 4 Reasons for reading periodical press and visiting news websites.

\section{Conclusion}

The internet has had significant impact on traditional journalism and publication of newspapers and magazines. On one hand, it enabled publication of information on current affairs in real time and enrichment of the content with audiovisual material, thereby making new media competitive with other media, mainly television and radio. On the other hand, it also considerably changed the way readers approach traditional editions of newspapers and magazines.

As a result of simple and fast access to information on the internet, readers stopped buying periodical press and replaced it with visits to news websites. This trend is most notable in the young generation of readers, who read traditional printed editions of newspapers and magazines sporadically, despite considering this way of obtaining information more convenient than visiting news websites. Intriguingly, the larger part of this generation of readers is not willing to pay for information published on the internet.

Contrary to the situation with the young generation, the middle and the older generations tend to visit news websites less frequently and prefer to read newspapers and magazines in their traditional printed form. In spite of their relatively infrequent visits, we discovered greater willingness to pay for information published on the internet than in the case of the youngest generation of readers. For the older and the middle generation of readers, however, news websites are not the primary source of information and therefore, they are not motivated to more frequent visits. For these generations, this function is perfectly fulfilled by traditional newspapers and magazines. According to the research of D. Petranová, as many as $51 \%$ of seniors read a newspaper every day or nearly every day [10].

Due to increasing publication costs of traditional titles of periodical press, their falling readership figures as well as decreasing amounts of funds invested in advertising in newspapers and magazines, many editorial boards will be forced to resolve the vital issues concerning operation cost which affect their future existence. The parallel existence of printed titles alongside their online versions - the so called news portals - in its present form will not be possible. Imposing charges on online content is facing the problem of relatively low interest of readers, whose needs in this regard are commonly satisfied by content accessible for free, or their ability to find the same information on other portals without the need to pay for it. That creates the idea of unlimited access to information on the internet. [11]

One possible way out of this problem might lie in creating unique content not available on other portals, which the readers would be willing to pay for. However, that would require placing greater demand on the journalistic discourse and the quality of journalists, which would bring increased costs for the editorial boards. Therefore, we see the solution in a superior marketing strategy of publishing houses and in the need for more targeted communication of particular products.

\section{Acknowledgment}

The paper is a part of research project VEGA 1/0640/15 named: „Phygital Concept and Its Use in Sustainable Integrated Environmental Management of Businesses“.

\section{References}

[1] Višňovský, J., „Mimoriadne udalosti a ich vplyv na štruktúru novín prípad denníka SME,“ Communication Today, vol. 2, issue 2, pp. 91106, 2011. ISSN 1338-130X

[2] Bezáková, Z., „Green computing practices as a part of the way to thesustainable development," in Environmental Software Systems:Fostering Information Sharing, Jiří Hřebíček ... [et al.], Eds. Heidelberg / New York / Dordrecht / London: Springer, 2013, pp. 579-587. ISBN 978-3-642-41150-2

[3] Kusá, A., Pizano, V., Marketingové analýzy a stratégie, Trnava: UCM, 2011, 196 p. ISBN 978-80-8105-239- 2

[4] Hradiská, E., Brečka, S., Vybíral, Z., Psychológia médií, Eurokódex: Bratislava, 2009, 416 p. ISBN 978-80-89447-12-1

[5] McLuhan, M., Jak rozumět mediím. Extenze člověka. Odeon: Praha, 1991, 400 p. ISBN 80-207-0296-2

[6] Tušer, A., Ako sa robia noviny, SOFA: Bratislava, 2003, p. 154. ISBN 978-80-89447-23-7

[7] Solík, M., Višňovský, J., Laluhová, J., „Media as a tool for fostering values in the Contemporary Society," European Journal of Science and Theology, vol. 9, issue 6, p. 76, 2013. ISSN 1842 - 8517. ISSN 1338-1 $30 \mathrm{X}$

[8] Krajčovič, P., „Innovation in printed media, “ in press.

[9] How People Use Tablets and What it Means for the Future of News, online, 2011. Available at: <http://www.journalism.org/2011/10/25/ta blet/>

[10] Petranová, D., Mediálna gramotnost' seniorov, Trnava: FMK UCM v Trnave, 2013, p. 105. ISBN 978-80-8105-496-9

[11] Mendelová, D., Zaušková, A.: Innovation in the Slovak Advertising Environment. In Communication Today, 2015, Vol. 6., No. 1., ISSN 1338-130X 